\begin{tabular}{c|l|l|l}
$\begin{array}{c}\text { Case Reports in } \\
\text { Oncology }\end{array}$ & $\begin{array}{l}\text { Case Rep Oncol 2011;4:101-105 } \\
\text { DOI: 10.1159/000324920 }\end{array}$ & $\begin{array}{l}\text { Published online: } \\
\text { February 25, 2011 }\end{array}$ & $\begin{array}{l}\text { O 2011 S. Karger AG, Basel } \\
\text { ISSN 1662-6575 } \\
\text { www.karger.com/cro }\end{array}$ \\
\hline
\end{tabular}

\title{
A Case of Disseminated and Fulminant Plasmacytomas That Developed during Bortezomib Treatment
}

\author{
Soo-Young Bae ${ }^{\mathrm{a}}$ Jae-Sook Ahn ${ }^{\mathrm{a}}$ Deok-Hwan Yang ${ }^{\mathrm{a}}$ \\ Yeo-Kyeoung Kim ${ }^{\mathrm{a}}$ Jung-Joon Min ${ }^{\mathrm{b}}$ Ho-Chun Song ${ }^{\mathrm{b}}$ \\ Hee-Seung Bom ${ }^{b}$ Yong Yeon Jeong ${ }^{c}$ Hyeoung-Joon Kim ${ }^{a}$ \\ Je-Jung Lee ${ }^{a, d}$
}

Departments of a Hematology-Oncology, ${ }^{b}$ Nuclear Medicine, and 'Radiology, Chonnam National University Hwasun Hospital, Hwasun, and ${ }^{\mathrm{d}}$ The Brain Korea 21 Project, Center for Biomedical Human Resources at Chonnam National University Medical School, Gwangju, Korea

\section{Key Words}

Multiple myeloma - Bortezomib - Fulminant plasmacytoma

\begin{abstract}
Multiple myeloma is an incurable and slow growing plasma cell neoplasm. The introduction of new drugs has increased the number of treatment options. Bortezomib, the first-in-class proteasome inhibitor, has been shown to have a significant antitumor activity in the treatment of relapse/refractory patients with multiple myeloma.

Additionally, plasmacytomas have shown significant response to bortezomib. In this case report, we describe a patient who developed disseminated and fulminant extramedullary plasmacytomas during combination chemotherapy treatment with bortezomib within a short period, after having shown clinical improvement.
\end{abstract}

\section{Introduction}

Multiple myeloma is a plasma cell malignancy characterized by slow progression. It follows a recurrent course that can become refractory to treatment over time. Combination chemotherapy including bortezomib, thalidomide, and lenalidomide is a highly effective salvage therapy for patients with relapsing or refractory multiple myeloma [1]. The development of soft tissue plasmacytomas has been reported in $15-20 \%$ of patients at the time of diagnosis and in an additional 15\% during the course of the disease [2]. Many cases of relapsed multiple myeloma with large soft tissue plasmacytomas have

Je-Jung Lee, MD, PhD 
shown significant response to bortezomib [3-5]. Here, we present a rare case of disseminated and fulminant extramedullary plasmacytomas that developed during combination chemotherapy treatment with bortezomib within a short period, after having shown clinical improvement.

\section{Case Report}

In June 2009, a 60-year-old man was referred to our hospital with back pain. The laboratory values were as follows: hemoglobin $10.4 \mathrm{~g} / \mathrm{dl}$, creatinine $1.4 \mathrm{mg} / \mathrm{dl}$, total calcium $11.1 \mathrm{mg} / \mathrm{dl}$, albumin $4.8 \mathrm{~g} / \mathrm{dl}$, 32-microglobin 14,045.4 mg/l, free kappa-chain $96.2 \mathrm{mg} / \mathrm{l}$, free lambda-chain $5.50 \mathrm{mg} / \mathrm{l}$, and plasma cells $79 \%$ in the bone marrow aspirate. The patient was diagnosed as having multiple myeloma, kappatype light-chain disease. The myeloma was in the late stage, according to the International Scoring System (III) and Durie-Salmon stage (IIIA). The patient was treated with 4 cycles of combination chemotherapy consisting of cyclophosphamide, thalidomide, and dexamethasone [6], followed by an autologous stem cell transplantation after conditioning with melphalan in December 2009. He achieved a very good partial response in January 2010. In addition, he received maintenance therapy with thalidomide and prednisolone for 4 months.

Due to persistent thrombocytopenia, a bone marrow biopsy was performed on the patient that showed diffuse infiltration of plasma cells and the free light chain was elevated, with the following values: kappa $171 \mathrm{mg} / \mathrm{l}$ and lambda $4.50 \mathrm{mg} / \mathrm{l}$, with a ratio of 38 . Salvage chemotherapy was performed with bortezomib $\left(1.3 \mathrm{mg} / \mathrm{m}^{2}\right.$ for days $1,4,8$, and 11$)$, cyclophosphamide (150 $\mathrm{mg} / \mathrm{m}^{2}$ for days $\left.1-4\right)$, and dexamethasone $\left(20 \mathrm{mg} / \mathrm{m}^{2}\right.$ for days $1,4,8$, and 11) [7]. After the first cycle of chemotherapy, the free light chain ratio returned to the normal level. Due to grade 3 asthenia, the patient could not receive consecutive cycles of chemotherapy. Forty days after the first cycle of chemotherapy, the patient complained of an oral mass in the hard palate, progressive grade 4 asthenia, and abdominal bloating. Computed tomography scan showed disseminated mesenteric, hepatic, and abdominal wall metastatic multiple nodular lesions (fig. 1a). Whole-body positron emission tomography showed similar lesions in addition to brain involvement (fig. 1b). Biopsies from the oral and abdominal soft tissue masses confirmed fulminant disseminated plasmacytomas. The patient was treated with melphalan and dexamethasone, but the disease progressed and he died within 4 weeks after the diagnosis of disseminated plasmacytomas.

\section{Discussion}

Multiple myeloma is a plasma cell malignancy characterized by paraproteinemia, immune paresis, skeletal destruction, renal dysfunction, anemia, and hypercalcemia [8]. The development of soft tissue plasmacytomas has been reported in $15-20 \%$ of patients at the time of diagnosis and in an additional 15\% during the course of the disease [2]. No association was found between the pattern of relapse and any of the clinical characteristics at the time of diagnosis [9]. In transplant groups, the median relapse time of a plasmacytoma form was 24 months; hence, it was longer compared to classic, insidious or transformed diseases [9].

Bortezomib has recently been approved for the treatment of relapsed or refractory myeloma based on large studies, and these trials demonstrated $30-40 \%$ response rates, including $10 \%$ complete response or near complete response as a single agent in a salvage setting $[10,11]$. Bortezomib in combination with other drugs improved the complete response rates up to approximately $47-50 \%$ in salvage treatment $[7,12]$. In relapsed patients with a plasmacytoma form, bortezomib is an effective treatment agent compared to thalidomide [2]. Laura et al. [2] reported that bortezomib may be useful in clinical situations of extramedullary disease. On the contrary, Ali et al. [13] reported that 
bortezomib might not be an effective agent for secondary extramedullary disease in salvage treatment for huge plasmacytoma. They explained this clinical feature with the concept that the tumor biology of secondary plasmacytomas may be different from the primary diseases.

In our case, the patient showed a normalization of the light chain ratio after the first cycle of combination chemotherapy with bortezomib, but a new fulminant and disseminated plasmacytoma developed after 40 days. It is possible that patients relapsing from complete response have a more aggressive emerging clone than patients progressing from an insidious form to non-complete response [9]. So, our report shows the rare case of fulminant plasmacytomas development during bortezomib treatment within a short period of time.

\section{Disclosure Statement}

The authors have no financial conflicts of interest. 


\begin{tabular}{c|l|l|l}
$\begin{array}{c}\text { Case Reports in } \\
\text { Oncology }\end{array}$ & $\begin{array}{l}\text { Case Rep Oncol 2011;4:101-105 } \\
\text { DOl: 10.1159/000324920 }\end{array}$ & $\begin{array}{l}\text { Published online: } \\
\text { February 25, 2011 }\end{array}$ & $\begin{array}{l}\text { O 2011 S. Karger AG, Basel } \\
\text { ISSN 1662-6575 } \\
\text { www.karger.com/cro }\end{array}$ \\
\hline
\end{tabular}
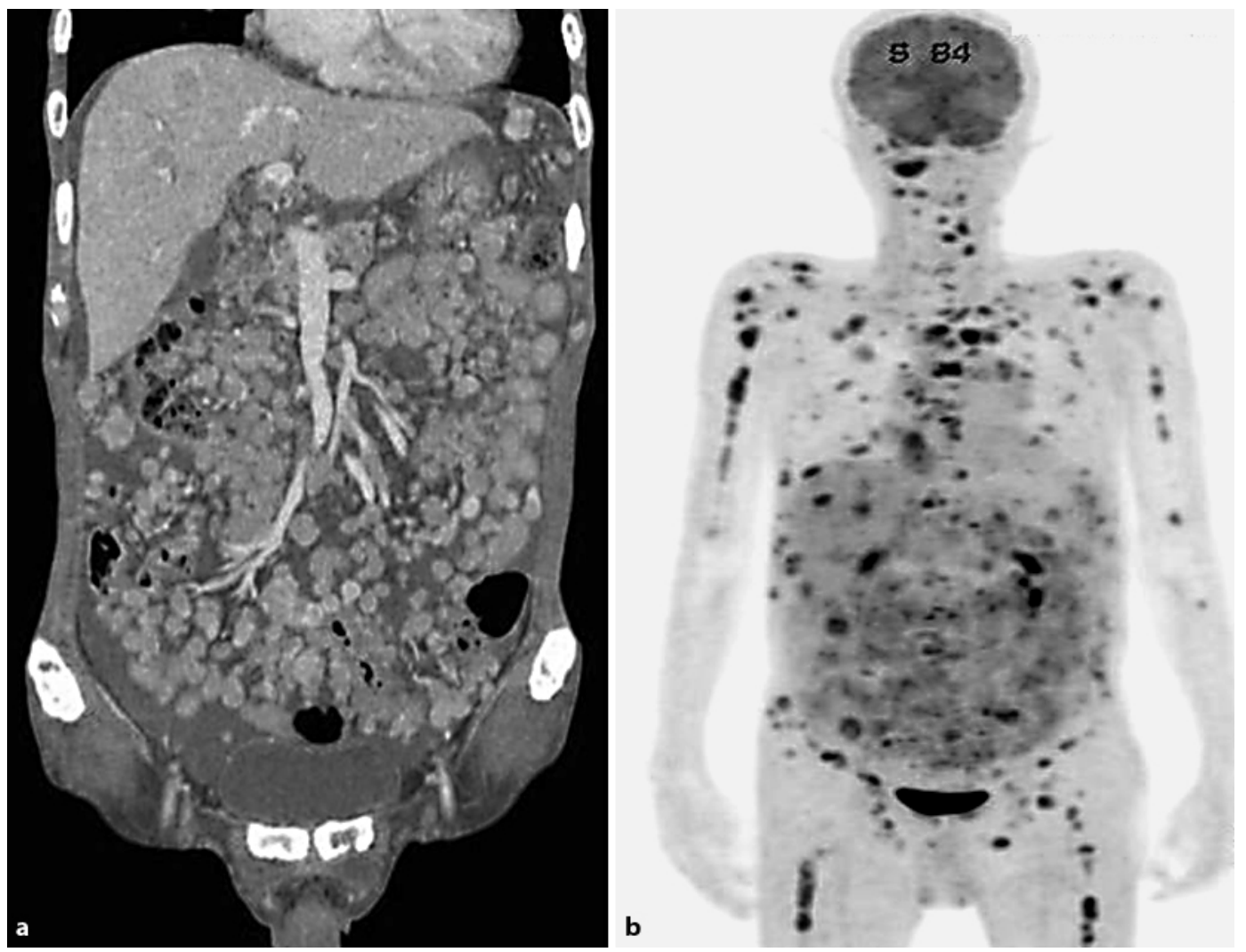

Fig. 1. Appearance of disseminated extramedullary plasmacytomas. a Computed tomography scan of the abdomen showing numerous nodular enhancing lesions in the abdominal cavity with hepatic invasion. b Positron emission tomography scan showing disseminated malignant lesions in the multiple skeleton, brain, mediastinum, lung, abdominal cavity, retroperitoneum, liver and adrenal gland. 


\section{References}

1 Laubach JP, Mahindra A, Mitsiades CS, Schlossman RL, Munshi NC, Ghobrial IM, Carreau N, Hideshima T, Anderson KC, Richardson PG: The use of novel agents in the treatment of relapsed and refractory multiple myeloma. Leukemia 2009;23:2222-2232.

-2 Laura R, Cibeira MT, Uriburu C, Yantorno S, Salamero O, Blade J, Montserrat E: Bortezomib: an effective agent in extramedullary disease in multiple myeloma. Eur J Haematol 2006;76:405-408.

-3 Dytfeld D, Matuszak M, Lewandowski K, Komarnicki M: Bortezomib in combination with thalidomide and dexamethasone - a successful treatment regimen in refractory extramedullary multiple myeloma. Ann Hematol 2008;87:253-254.

-4 Fukushima T, Nakamura T, Miki M, Sakai T, Iwao H, Nakajima A, Sawaki T, Fujita Y, Tanaka M, Masaki Y, Hirose Y, Umehara H: Complete response obtained by bortezomib plus dexamethasone in a patient with relapsed multiple myeloma with multiple plasmacytomas. Anticancer Res 2010;30:3791-3794.

-5 Varettoni M, Mangiacavalli S, Zappasodi P, Pica GM, Lazzarino M, Corso A: Efficacy of Bortezomib followed by local irradiation in two patients with extramedullary plasmacytomas. Leuk Res 2008;32:839-841.

-6 Yang DH, Kim YK, Sohn SK, Chung JS, Joo YD, Lee JH, Lee JL, Ahn JS, Moon JH, Shin HJ, Choi YJ, Lee WS, Kim HJ, Lee JJ: Induction treatment with cyclophosphamide, thalidomide, and dexamethasone in newly diagnosed multiple myeloma: a phase II study. Clin Lymphoma Myeloma Leuk 2010;10:62-67.

-7 Kim YK, Sohn SK, Lee JH, Yang DH, Moon JH, Ahn JS, Kim HJ, Lee JJ: Clinical efficacy of a bortezomib, cyclophosphamide, thalidomide, and dexamethasone (Vel-CTD) regimen in patients with relapsed or refractory multiple myeloma: a phase II study. Ann Hematol 2010;89:475-482.

-8 Kyle RA, Rajkumar SV: Multiple myeloma. N Engl J Med 2004;351:1860-1873.

$\triangleright_{9}$ Lenhoff S, Hjorth M, Turesson I, Westin J, Gimsing P, Wisloff F, Ahlberg L, Carlson K, Christiansen I, Dahl IM, Forsberg K, Brinch L, Hammerstrom J, Johnsen HE, Knudsen LM, Linder O, Mellqvist UH, Nesthus I, Nielsen JL: Intensive therapy for multiple myeloma in patients younger than 60 years. Long-term results focusing on the effect of the degree of response on survival and relapse pattern after transplantation. Haematologica 2006;91:1228-1233.

10 Richardson PG, Barlogie B, Berenson J, Singhal S, Jagannath S, Irwin D, Rajkumar SV, Srkalovic G, Alsina M, Alexanian R, Siegel D, Orlowski RZ, Kuter D, Limentani SA, Lee S, Hideshima T, Esseltine DL, Kauffman M, Adams J, Schenkein DP, Anderson KC: A phase 2 study of bortezomib in relapsed, refractory myeloma. N Engl J Med 2003;348:2609-2617.

-11 Richardson PG, Sonneveld P, Schuster M, Irwin D, Stadtmauer E, Facon T, Harousseau JL, Ben-Yehuda D, Lonial S, Goldschmidt H, Reece D, Miguel JS, Blade J, Boccadoro M, Cavenagh J, Alsina M, Rajkumar SV, Lacy M, Jakubowiak A, Dalton W, Boral A, Esseltine DL, Schenkein D, Anderson KC: Extended follow-up of a phase 3 trial in relapsed multiple myeloma: final time-to-event results of the APEX trial. Blood 2007;110:35573560.

12 Lee SS, Suh C, Kim BS, Chung J, Joo YD, Ryoo HM, Do YR, Jin JY, Kang HJ, Lee GW, Lee MH, Shim H, Kim K, Yoon SS, Bang SM, Kim HY, Lee JJ, Park J, Lee DS, Lee JH: Bortezomib, doxorubicin, and dexamethasone combination therapy followed by thalidomide and dexamethasone consolidation as a salvage treatment for relapsed or refractory multiple myeloma: analysis of efficacy and safety. Ann Hematol 2010;89:905-912.

-13 Ali R, Ozkalemkas F, Ozkan A, Ozkocaman V, Ozcelik T, Ozan U, Kurt M, Tunali A: Bortezomib and extramedullary disease in multiple myeloma: the shine and dark side of the moon. Leuk Res 2007;31:11531155. 